\title{
Giant Lipoma of the Scalp in Aba, South East Nigeria: A Case Report
}

\author{
Ndukauba Eleweke \\ Department of Surgery, Abia State University, Uturu, Nigeria \\ Email: ndukauba.eleweke@abiastateuniversity.edu.ng
}

How to cite this paper: Eleweke, N. (2021) Giant Lipoma of the Scalp in Aba, South East Nigeria: A Case Report. Open Access Library Journal, 8: e7898.

https://doi.org/10.4236/oalib.1107898

Received: August 27, 2021

Accepted: October 9, 2021

Published: October 12, 2021

Copyright ( 2021 by author(s) and Open Access Library Inc.

This work is licensed under the Creative Commons Attribution International License (CC BY 4.0).

http://creativecommons.org/licenses/by/4.0/

\section{(c) (i) Open Access}

\begin{abstract}
Lipomas are ubiquitous soft tissue swellings that can be found in any part of the body. They are the commonest non-malignant tumours of the fatty tissue with varying sizes. When they are more than $10 \mathrm{~cm}$ in size along any dimension or weigh more than $1000 \mathrm{~g}$, they are described as giant lipomas. I present a case of giant lipoma of the scalp, managed in Jonex Hospital, Aba, Nigeria. After clinical and relevant radiological investigations to characterize and ascertain the extent of the scalp lesion, and ensure patients suitability for surgery, the mass was excised surgically. The specimen underwent histology to confirm the diagnosis. From available literature search, this is the first case of giant Lipoma of the Scalp reported from this area. Conclusion: giant lipoma of the scalp in Aba, Abia State of Nigeria has been diagnosed and adequately treated by surgical excision.
\end{abstract}

\section{Subject Areas}

Oncology

\section{Keywords}

Giant Lipoma, Scalp, Subcutaneous Tissue, Aba

\section{Introduction}

Lipomas are benign fatty tumours that can occur anywhere in the body where there is fat [1]. They are majorly found in the subcutaneous layers, occurring in all ages, but they are more commonly seen in adults aged between 40 and 60 years [2]. They originate from primordial fat cells, so they increase in size with accumulation of adipose tissue, but weight loss does not affect the size [3] [4].

They are mostly solitary but may be multiple. For solitary lipomas the male: female ratio is about the same, but females tend to have higher incidence of mul- 
tiple lipomas [5].

Lipomas could be superficial when they can be encapsulated or non encapsulated, or deep [6]. Superficial lipomas are more common than deep lipomas [6]. Deep lipomas are generally larger than superficial lipomas and could be intermuscular, intramuscular, interosseous or visceral, displacing adjacent structures [7].

Lipomas are described as giant when they weigh more than $1 \mathrm{~kg}$ or measure more than $10 \mathrm{~cm}$ in any dimension [8]. Giant Lipomas can get infected, have adverse cosmetic effects, limit movement, cause pain, lymphoedema, pressure symptoms and may undergo malignant transformation [9].

Giant lipomas of various parts of the body have been reported. Emegoakor et al. in Awka Nigeria, reported giant lipomas of the gluteal region and lower limb [10]. Nakamura Y et al. [11], Chatterton BD et al. [12], Danzi M et al. [13] have also reported Giant Lipomas of various anatomical regions. Brandler [4] in 1894 reported a lipoma of the left scapular region in a 26 -year-old man which weighed about $22.7 \mathrm{~kg}$. This is the largest reported lipoma in English literature.

I present giant lipoma of the scalp in a 23-year-old female Nigerian in Aba, South East Nigeria. From available literature, this is the first case of such a lipoma to be reported from this area.

\section{Case Report}

A 23 years old female presented to us with progressively increasing swelling on the head of about 6 years duration. The swelling has remained painless with no constitutional disturbance. She however cannot expose her head in public because of the embarrassing size and shape of her head.

There was no history of trauma and no similar swelling elsewhere in the body. There was no family member with a similar swelling.

The past medical and surgical histories were unremarkable.

Physical examination showed a healthy-looking young girl. The vital signs were normal. Her body mass index was $19.4 \mathrm{~kg} / \mathrm{m}^{2}$. Significant findings were on the head where an elliptical mass measuring $15 \times 12 \times 10 \mathrm{~cm}$ was located. It extended from the frontal region to the occiput and laterally to the parietal regions (Figure 1).

The mass was freely mobile in all directions, firm and non-tender. It was non-pulsatile and non-compressible. The overlying skin was normal with normal hair growth over the swelling (Figure 2). There was no palpable cervical lymphadenopathy.

We made a diagnosis of giant lipoma of the scalp. Blood work including lipid profile was normal. Plain x-ray of the skull revealed a well-circumscribed soft tissue mass with no attachment to bone and no bony defect (Figure 3).

The patient was worked up for excision biopsy. In theatre under general anaesthesia, with patient in prone position, an elliptical skin incision was made over the swelling. An encapsulated fatty mass under the subcutaneous layer was shelled out (Figure 4). The wound was closed over an active drain. 


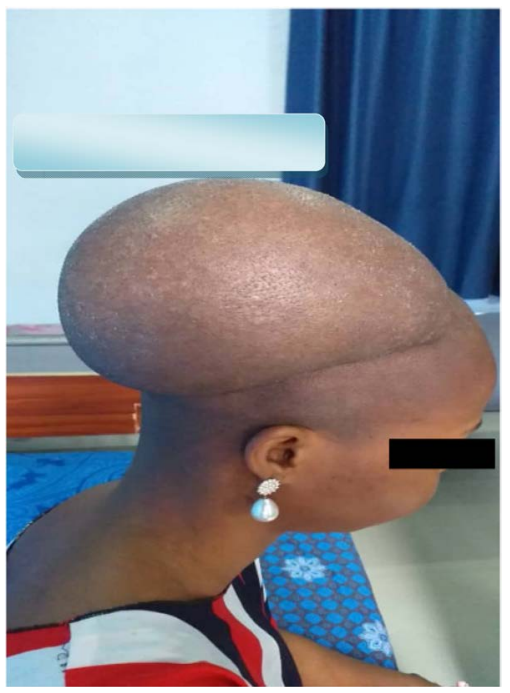

Figure 1. The scalp swelling at presentation.

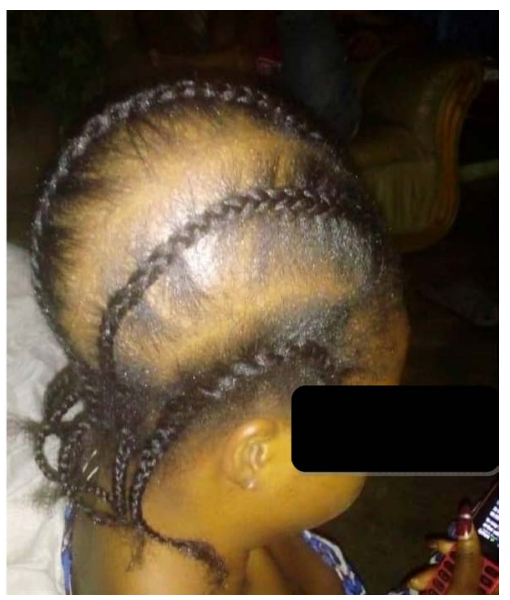

Figure 2. Normal hair growth over the scalp swelling.

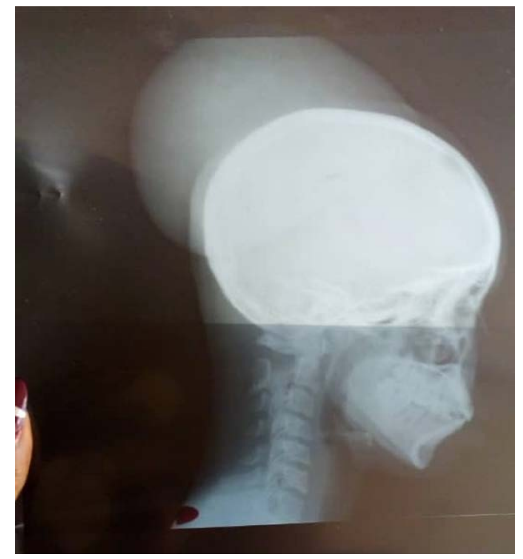

Figure 3. Plain skull x-ray showing soft tissue swelling of the scalp with no bone involvement. 


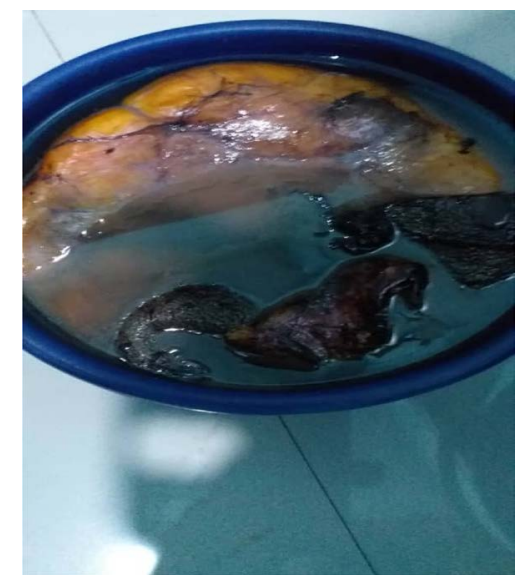

Figure 4. The specimen excised from the scalp of the patient with giant lipoma of the scalp.

The mass which weighed $3.7 \mathrm{~kg}$ was sent for histology. The result of histology showed the mass to be fibrolipoma. The post-operative period was unremarkable and she was discharged home after three days. Eighteen months after the surgery, she has remained in good clinical condition and is happy with the treatment.

\section{Discussion}

Lipomas are slow-growing benign tumours of the fatty tissue, with a few attaining gigantic sizes [1] [4]. Although the exact cause of lipoma is not known, it has been associated with genetic abnormalities, familial tendencies [2] obesity, hypercholesterolaemia, and trauma [1] [11].

The reasons for lipomas attaining gigantic sizes have not been ascertained but theories abound including the role of trauma. Trauma is said to induce release of cytokines which cause differentiation and maturation of pre-adipocytes [8] [9]. Trauma is also postulated to lead to separation of fibrous septa and connections between the skin and deep fascia making the fat cells proliferate rapidly [9]. Trauma may also lead to herniation of the lipoma through fascia planes causing pseudo lipomas [9]. Familial and genetic abnormalities and hypercholesterolaemia have also been postulated as possible aetiological factors of giant lipoma [1]. In the index patient, there were none of the above predisposing conditions to lipoma.

Lipomas rarely undergo malignant transformation into liposarcomas-the most common soft tissue malignancy in long-standing lipomas [2]. Malignant transformations occur more when there is delayed diagnosis as in retroperitoneal lipomas. [12]. When lipoma increases in size, becomes painful, deep-seated, intramuscular in position and irregular in shape, the likelihood of malignant transformation is high [2]. The malignant nature or otherwise of the lipoma can be ascertained by ultrasonography, CT Scan, MRI, and needle biopsy [14].

Open surgical excision as in the index case is the treatment of choice. The en- 
capsulation of lipomas makes the surgery relatively easy. There is a need for careful dissection and control of bleeding to prevent damage to surrounding structures and formation of haematoma and seroma postoperatively.

The excised specimen should be subjected to histopathological examination to rule out malignancy [15]. In this index case, the result came out as fibrolipoma.

\section{Conclusion}

We have presented the first case of giant lipoma of the scalp seen and successfully managed in Aba, South East Nigeria. From literature search, no such giant scalp lipoma has been seen and managed in Aba, South East Nigeria.

\section{Conflicts of Interest}

The author declares no conflicts of interest.

\section{References}

[1] Singh, M., Saxena, A., Kumar, L., Karande, L.K. and Kolhe, Y. (2014) Giant Lipoma of Posterior Cervical Region. Case Reports in Surgery, 2014, Article ID: 289383. https://doi.org/10.1155/2014/289383

[2] Rydholm, A. and Berg, N.O. (1983) Site, Size and Clinical Incidence of Lipoma. Factors in the Differential Diagnosis of Lipoma and Sarcoma. Acta Orthopaedica Scandinavica, 54, 929-934. https://doi.org/10.3109/17453678308992936

[3] Allen, B., Radar, C. and Babigian, A. (2007) Giant Lipoma of the Upper Extremity. The Canadian Journal of Plastic Surgery, 15, 141-144. https://doi.org/10.1177/229255030701500308

[4] Brandler, T.I. (1894) Large Fibrolipoma. British Medical Journal, 1, 574.

[5] Nigri, G., Dente, M., Valabrega, S., Beccaria, G., Aurelio, P.D., Angelo, F., et al. (2008) Giant Inframuscular Lipoma Disclosed 14 Years after a Blunt Trauma: A Case Report. Journal of Medical Case Reports, 2, Article No. 318. https://doi.org/10.1186/1752-1947-2-318

[6] Di, B., Enedetto, G., Aquinati, A., Astolffi, M. and Bertani, A. (2004) Giant Compressing Lipoma of the Thigh. Plastic and Reconstructive Surgery, 114, 1983-1985. https://doi.org/10.1097/01.PRS.0000143929.24240.9A

[7] Roberts, C.C., Liu, P.T. and Colby, T.V. (2003) Encapsulated versus Non-Encapsulated Superficial Fatty Masses; a Proposed MR Imaging Classification. American Journal of Roentgenology, 180, 1419-1422. https://doi.org/10.2214/ajr.180.5.1801419

[8] Sanchez, M.R., Golomb, F.M., Moy, J.A. and Potozkin, J.R. (1993) Giant Lipoma: Case Report and Review of Literature. Journal of the American Academy of Dermatology, 28, 266-268. https://doi.org/10.1016/S0190-9622(08)81151-6

[9] Kshirsagar, A.Y., Nangare, N.R., Gupta, V., Vekeriya, M.A., Patankar, R., Mahna, A., et al. (2014) Multiple Giant Intra Abdominal Lipomas: A Rare Presentation. International Journal of Surgery Case Reports, 5, 399-402. https://doi.org/10.1016/j.ijscr.2014.04.002

[10] Emegoakor, C.D., Echezona, C.N., Onwukamuche, M.E. and Nzeakor, H.O. (2017) Giant Lipomas. A Report of Two Cases. Nigerian Journal of General Practice, 15, 46-49. https://doi.org/10.4103/NJGP.NJGP_17_16

[11] Nakamura, Y., Teramato, Y., Sato, S., Yamada, K., Fujisada, Y., Fujumoto, M., et al. 
(2014) Axillary Giant Lipoma: A Report of 2 Cases and Published Review. The Journal of Dermatology, 41, 841-844. https://doi.org/10.1111/1346-8138.12598

[12] Chatterton, B.D., et al. (2013) An Exceptionally Large Giant Lipoma of the Hand. BMJ Case Reports, 2013, bcr2013200206. https://doi.org/10.1136/bcr-2013-200206

[13] Danzi, M., Grimaldi, L., Reggio, S. and Danzi, R. (2010) Giant Atypical Lipoma of the Thigh. Case Report and Literature Review. Il Giornale di Chirurgia, 31, 108-111.

[14] Yakubu, A.A., Edino, S.T., Mohammed, A.Z., Sheshe, A.A. and Alhassan, S.U. (2008) Giant and Complicated Subcutaneous Lipoma of the Neck. West African Journal of Medicine, 27, 44-46.

[15] Guler, O. (2015) Giant Lipoma of the Back Affecting Quality of Life. Annals of Medicine and Surgery, 4, 279-282. https://doi.org/10.1016/j.amsu.2015.08.001 